\title{
The impact of microcredit on poverty reduction in eleven developing countries in south-east Asia
}

\author{
Elisabete Gomes Santana Félix ${ }^{\mathrm{a}, *}$, Teresa Freitas Belo ${ }^{\mathrm{b}}$ \\ a University of Évora, Management Department and CEFAGE-UÉ, Largo dos Colegiais, $n^{\circ}$ 2, 7000-803, Évora, Portugal \\ b University of Évora, Management Department, Largo dos Colegiais, $n^{\circ} 2,7000-803$, Évora, Portugal
}

\section{A R T I C L E I N F O}

\section{Article history:}

Received 11 December 2018

Received in revised form 22 July 2019

Accepted 25 July 2019

Available online $\mathrm{xxx}$

\section{JEL classification:}

C33

C36

G21

I3

01

Keywords:

Employment

Inflation rate

Level of education

Microcredit

Poverty gap

Poverty reduction

\begin{abstract}
A B S T R A C T
This paper examines the impact of microcredit on poverty reduction, controlling for income and its distribution, employment, inflation rate and education, in 11 developing countries in south-east Asia.

Static and dynamic panel data models were used in the growth-poverty model initially suggested by Ravallion (1997), with data from 2007 to 2016.

The results indicate that microcredit reduces poverty (as measured by the headcount index, poverty gap and squared poverty gap). They also indicate that employment and education can reduce the level of poverty.
\end{abstract}

(C) 2019 Elsevier B.V. All rights reserved.

\section{Introduction}

Poverty is a complex phenomenon involving multiple deprivations. The economic definition of poverty states that an individual is deemed poor if unable to attain a minimal standard of living. Poverty alleviation cannot be defined only in economic terms but is also about addressing a much broader set of needs. Amartya Sen, the Nobel Prize-winning economist, eloquently argues that development can be seen as a "process of expanding the real freedoms that people enjoy". Social, cultural and political freedoms are desirable in and of themselves, and they also enable growth in individual income. Services such as public safety, basic education, public health, and infrastructure nurture these freedoms and increase the productivity and employability of the poor, and thus their income and well-being (Yunus, 2009).

Poverty is still one of the world's greatest problems, such that one of the millennium development goals (MDGs) was to reduce the poverty headcount rate worldwide, and in 2015, the first sustainable development goal (SDG) from the SDG agenda continues to be to "end poverty in all its forms everywhere".

\footnotetext{
* Corresponding author.

E-mail addresses: efelix@uevora.pt (E.G.S. Félix), teresafreitas.belo@hotmail.com (T.F. Belo).
} 